\title{
Irrigation Practices as Alternative Means of Supporting Rain-fed Agriculture: A Case Study of Potato (Solanum tuberosum $\boldsymbol{L}$.)
}

\author{
Solomon Abirdew Yirga \\ Wolkite University Department of Natural Resource Management, Wolkite, Ethiopia
}

\begin{abstract}
Estimation of evapotranspiration is important for study, design, determining crop water requirement and management of irrigation systems. Also it's important for determining irrigation water requirement during dry spell and water shortage i.e. when the evapotranspiration is greater than effective rainfall. Based on this, the study was conducted in Cheha district, Gurage Zone with determine crop water requirement of potato. In line to this, ten years climatological recorded data (2008-2017) for Indibir station on (sunshine duration hr/day), maximum and minimum temperature $\left({ }^{\circ} \mathrm{C}\right)$, humidity $(\%)$ and wind speed $(\mathrm{km} / \mathrm{day})$ at 2 meters height were used to determine $\mathrm{ET}_{\mathrm{o}}$ using Penman combination method. Secondary data were used to collect important soil parameters required for determination of crop water requirement. Lengths of growing periods, planting date and crop varieties data were received from the validation value of the local farmers and CDAO. Crop coefficients $(\mathrm{kc})$, rooting depth, critical depletion fractions, yield response factors and crop height were obtained from food and agriculture organization of the United Nations guidelines (No. 56). The analyzed data indicated that reference crop evapotranspiration ranged from 2.40 to $4.73 \mathrm{~mm}$ with a mean of $3.56 \mathrm{~mm}$. The assessment has showed that the water requirement of potato is $63.2,84.1,145.8$ and $77.2 \mathrm{~mm}$ during initial, development, mid and late growth stages, respectively. The effective rainfall contribution throughout the growing stage of potato in the area is $8.5,23,187.2$ and $158.1 \mathrm{~mm}$ all through initial, development, mid and late growth stages, whereas the net irrigation requirement of potato throughout the dry spell period is $52.9,61.3,14.9$ and $0 \mathrm{~mm}$ in initial, development, mid and late growth stages, respectively. Soil and water conservation management practice, water harvesting technology and agronomic practices should be applied, principally mulching is very important to save soil moisture during high heat stress and dry spell or water shortage.
\end{abstract}

Key terms: reference evapotranspiration, crop water requirement, potato

DOI: $10.7176 / \mathrm{JAAS} / 55-03$

Publication date:May $31^{\text {st }} 2019$

\section{Introduction}

The importance of rain-fed agriculture varies regionally but produces most food for poor communities in developing countries. In sub-Saharan Africa more than $95 \%$ of the farmed land is rain-fed, while the corresponding figure for Latin America is almost 90\%, for South Asia about 60\%, for East Asia $65 \%$ and for the Near East and North Africa 75\%. In the domain of agriculture sector, potato is one of the dominant tuber crops in Cheha district, it's used as food crop and economic value for the farmers. However, due to the nature of the crop, excess and low watering, and planting period (low rain during belg (small rainy season) causes for low potato production in the area. In addition to the above motive, lack of information on evapotranspiration, crop water requirement and net irrigation requirement are causes for low potato production in the area. This finding will tried to make information available on evapotranspiration, crop water requirement and net irrigation requirement for the farmers, NGOs, investor's and government who want to involve in the potato production in the area. Inline to this, the objective of the research is to determine crop water requirement, net irrigation requirement and water requirement satisfaction index of potato production in the area.

\section{Methods}

\subsection{Description of the study area}

The study was conducted in 2018 at Cheha district, Gurage zone, SNNP region on the southern west part of Ethiopia. Cheha district is located $182 \mathrm{~km}$ far from Addis Ababa and $24 \mathrm{~km}$ far from Wolkite town. Cheha district shares boundaries with Wabe River which separates it from Abeshge and Kebena from north, Oromia Region from west, Enemorina Eaner from south and Ezha from east [2]. The geographical location of the study area is ranged from $8^{\circ}, 0^{\prime}, 0^{\prime \prime}-8^{\circ}, 22^{\prime} 0^{\prime \prime} \mathrm{N}$ and $37 \mathrm{o}, 40^{\prime}, 0^{\prime \prime}-38 \mathrm{o}, 0^{\prime}, 0^{\prime \prime} \mathrm{E}$ (Figure 1). 


ISE

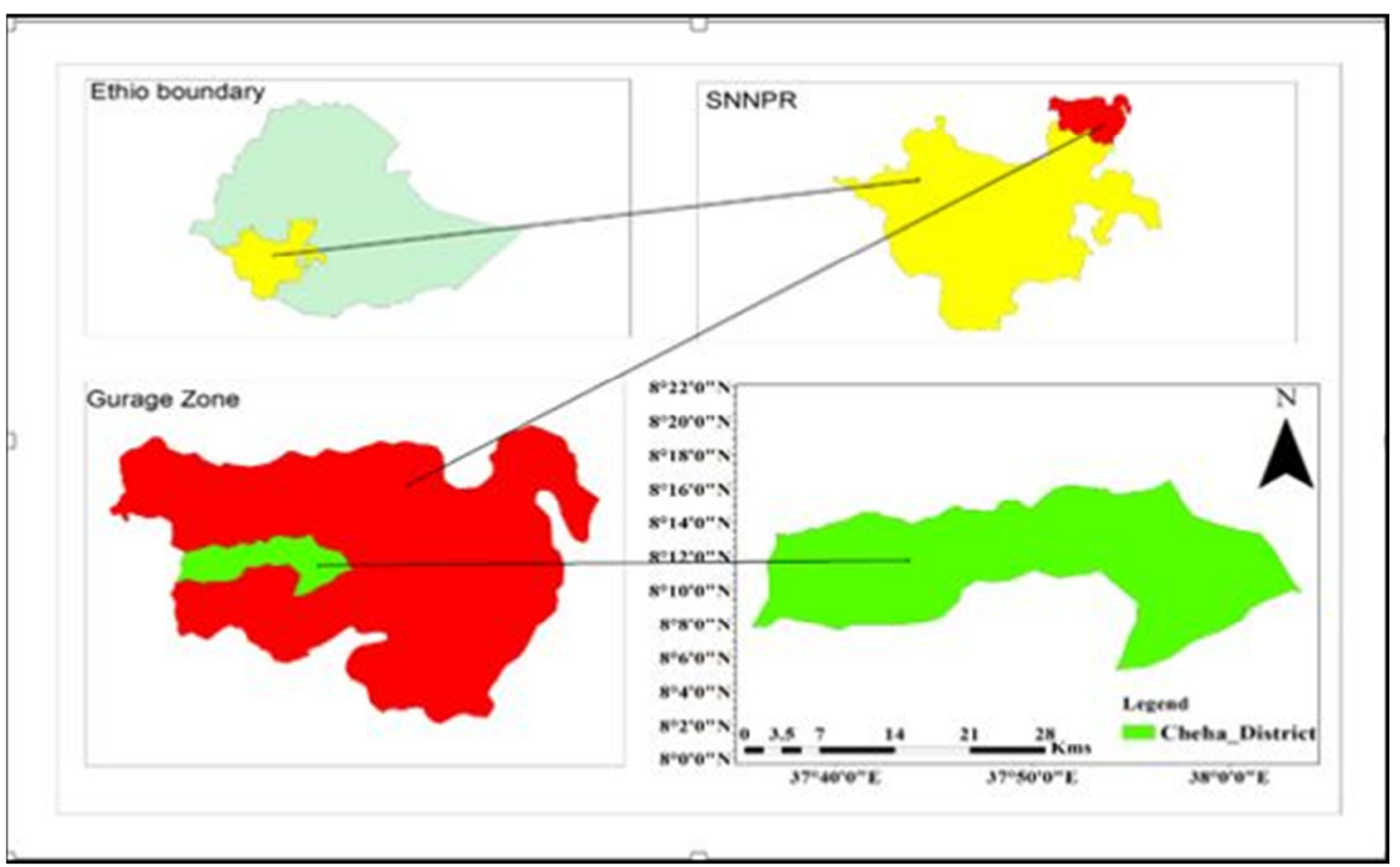

Figure 1: Location map of the study area (Source: Computed from ArcGIS10.3.1)

\subsection{Data collection and analysis}

\subsubsection{Climate data}

The sunshine duration (hr/day), rainfall $(\mathrm{mm})$, maximum and minimum temperature $\left({ }^{\mathrm{O}} \mathrm{C}\right)$, humidity $(\%)$ and wind speed $(\mathrm{km} /$ day) data were received from NMA and all climate parameters data were captured in to Microsoft excel 2013 spreadsheet following the day of year (DOY) entry format.

\subsubsection{Soil data}

Unpublished secondary data were used from Gurage zone soil laboratory to collect important soil parameters required for determination of crop water requirement in the study area such as field capacity(FC), permanent wilting point(PWP) and initial soil moisture depletion (as \% TAM). Available water holding capacity/total available soil moisture $(\mathrm{mm} / \mathrm{meter})$ were determined from FC and PWP, while data for maximum rain infiltration rates $(\mathrm{mm} /$ day $)$ and maximum rooting depth $(\mathrm{cm})$ were obtained from literature based on similar textural class of the soil in the study area.

\subsubsection{Crop data}

Crop related data is required to estimate the crop water requirements on daily, decadal and monthly bases. Crop water requirements were computed for potato which is widely grown as a food crop in the study area. Lengths of total growing periods of the crop were obtained from CDAO and farmers of study area and again the planting date was acquired from CDAO and farmers of the area. Crop coefficients $(\mathrm{kc})$ for potato defined as the ratio of the crop evapotranspiration (ETc) of a disease free crop grown in a large field adequately supplied with water to the reference crop evapotranspiration (ETo), rooting depth, depletion level and other agronomic parameters were acquired from FAO guidelines (No 56) for each growth stage [1].

\subsubsection{Reference crop evapotranspiration estimation}

Reference crop evapotranspiration for potato grown in the area was estimated from long term climate parameters (2008-2017) in CROPWAT 8.0 for window software. In the study area there is only 12 years long term climatological data on sunshine hours, humidity and wind speed. Therefore, in estimating ETo, 10 years (20082017) Indibir station climatological records of sunshine hours, maximum and minimum temperature, humidity and wind speed at 2 meters height were used in CROPWAT 8.0 software. Mathematical Penman Monteith (1965) form of model is as follows:

$$
\mathrm{ETo}_{\mathrm{o}}=\frac{0.408 \Delta(R n-G)+\gamma \frac{900}{T+273} \mathrm{U} 2(e s-e a)}{\Delta+\gamma(1+0.34 \mathrm{U} 2)}
$$

Where, ETo is reference crop evapotranspiration ( $\mathrm{mm} /$ day), $\mathrm{Rn}$ is net radiation at the crop surface $\left(\mathrm{MJ} \mathrm{m}^{-2}\right.$

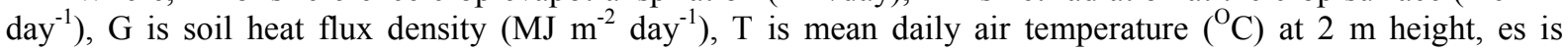
saturation vapour pressure $(\mathrm{kPa})$, ea is actual vapor pressure $(\mathrm{kPa})$, es-ea is saturation vapor pressure deficit $(\mathrm{kPa}), \Delta$ is slop vapor pressure curve $\left(\mathrm{kPa} /{ }^{\circ} \mathrm{C}\right), U 2$ is the average wind speed at $2 \mathrm{~m}$ height $(\mathrm{m} / \mathrm{s})$ and $\gamma$ is 
psychrometric constant $\left(\mathrm{kPa} /{ }^{\mathrm{O}} \mathrm{C}\right)$.

\subsubsection{Crop water requirement}

According to [7] in rain-fed cropping, the estimated crop water requirement is an important parameter to use alternate practices like mulching, reducing plant population by certain percentage in order to reduce the stiff competition. To estimate the reference evapotranspiration and crop water requirement the major climate parameters are crucial, following the rule and regulation of scientific investigation and theories, ten years (20082017) Indibir station climatological records of (sunshine duration $\mathrm{hr} /$ day), maximum and minimum temperature $\left({ }^{\mathrm{O}} \mathrm{C}\right)$, humidity $(\%)$ and wind speed $(\mathrm{km} /$ day) at 2 meters height will be used in FAO Penman Monteith model. In this study CROPWAT 8.0 software were used for analyzing ETo and ETc of potato. Experimentally determined ratio of ETc/ETo, crop coefficient $(\mathrm{kc})$ used to relate ETc to ETo. Mathematically expressed as:

$$
\mathrm{CWR}=\mathrm{ETc}=\mathrm{kc} * \mathrm{ETo}
$$

Where; $\mathrm{CWR}=\mathrm{Crop}$ water requirement, $\mathrm{ETc}=$ Crop evapotranspiration, ETo $=$ Reference crop evapotranspiration, $\mathrm{kc}=$ crop coefficient.

\subsubsection{Net irrigation requirement}

At the mean time it is possible to estimate net irrigation requirement of potato to offset dry spell or drought (water stress/shortage) condition throughout the growing period in addition to effective rainfall of that locality. Net irrigation requirement (NIR) expressed as the difference between crop water requirement (ETc) and effective rainfall (ER).

$$
\mathrm{NIR}=\mathrm{ETc}-\mathrm{ER}
$$

For effective rainfall method to crop water requirement determination, dependable rainfall (FAO/ AGLW) formula was applied it's mathematically noted as

$$
\begin{aligned}
& \mathrm{ER}=0.6 * \mathrm{P}-10 / 3 \\
& \text { requirement satisfaction index }
\end{aligned}
$$

\subsubsection{Water requirement satisfaction index}

Water requirement satisfaction index (WRSI) is an indicator of crop performance based on the availability of water to the crop during a growing season. The purpose of water requirement satisfaction index analyses is to characterize the study area in terms of the overall rainfall potential and constraints in growing season. WRSI can provides a gross picture for long-term research and development planning. WRSI is the ratio of seasonal effective (ER) to the seasonal crop water requirement (ETc) multiplied by 100 [6]. Mathematically noted as:

$\mathrm{WRSI}=\sum \mathrm{ER} / \sum \mathrm{ETC} * 100$

5

Where, WRSI is water requirement satisfaction index, ER is effective rainfall and ETc is crop water requirement.

\section{Results and Discussions}

\subsection{Reference crop evapotranspiration $\left(\mathbf{E T}_{0}\right)$}

As shown in Table 1, reference crop evapotranspiration ranged from 2.40 to $4.73 \mathrm{~mm}$ with a mean of $3.56 \mathrm{~mm}$ in the area. The maximum reference crop evapotranspiration was $4.73 \mathrm{~mm}$ that was experienced in 2009 (in the month of March), whereas the minimum reference crop evapotranspiration was $2.4 \mathrm{~mm}$ which was recorded in 2012 (in the month of July). This might be due to high and low maximum temperature during March and July in the study area, respectively.

Mean monthly reference evapotranspiration CV and SD ranged from $10.24-21.21 \%$ and $0.33-0.75 \mathrm{~mm}$, respectively. The proportion of variation $\left(\mathrm{R}^{2}\right)$ in mean monthly reference evapotranspiration explained by the year/month oscillated from $1-29 \%$ in the study area (Table 2). Study conducted in the central Rift Valley of Ethiopia by [8] also showed mean monthly crop evapotranspiration of $5.5 \mathrm{~mm}$

Table 1. Descriptive statistics of monthly evapotranspiration (ETo in $\mathrm{mm}$ ) in the study area (2008-2017)

\begin{tabular}{llllllllllll}
\hline Month & 2008 & 2009 & 2010 & 2011 & 2012 & 2013 & 2014 & 2015 & 2016 & 2017 \\
\hline Jan & 3.76 & 3.35 & 3.5 & 3.62 & 4.3 & 3.84 & 4.1 & 3.68 & 3.53 & 3.86 \\
Feb. & 4.18 & 3.97 & 3.24 & 3.83 & 4.59 & 4.62 & 3.64 & 4.29 & 4.13 & 3.83 \\
mar & 4.59 & 4.76 & 3.74 & 3.63 & 4.28 & 4.54 & 3.61 & 4.4 & 4.2 & 4.15 \\
Apr. & 3.92 & 4.04 & 3.48 & 4.46 & 4 & 4.52 & 3.88 & 4.55 & 3.65 & 4.43 \\
may & 3.39 & 4.06 & 3.08 & 3.84 & 4.09 & 3.42 & 3.31 & 3.64 & 3.56 & 3.54 \\
Jun. & 2.84 & 3.26 & 3.16 & 3.17 & 2.98 & 3.06 & 3.02 & 2.87 & 2.96 & 3.13 \\
Jull & 3.82 & 2.68 & 2.56 & 2.63 & 2.4 & 2.46 & 2.73 & 3.2 & 2.64 & 2.52 \\
Aug. & 2.61 & 2.86 & 2.74 & 2.72 & 2.6 & 2.59 & 2.79 & 3.18 & 2.83 & 2.75 \\
step & 3.11 & 3.07 & 3.25 & 3.1 & 2.86 & 2.81 & 3.23 & 3.31 & 3.15 & 3.08 \\
act & 3.53 & 3.4 & 3.33 & 3.71 & 3.76 & 3.26 & 3.99 & 3.79 & 3.64 & 3.68 \\
Nov & 3.47 & 3.75 & 3.47 & 3.51 & 3.79 & 3.7 & 4.15 & 3.87 & 3.57 & 3.68 \\
\hline dec & 3.57 & 3.1 & 3.43 & 3.74 & 3.66 & 3.55 & 4.06 & 3.8 & 3.6 & 3.6 \\
\hline
\end{tabular}


Table 2. Descriptive statistics of monthly evapotranspiration (ETo in mm) in the study area (2008-2017)

\begin{tabular}{llllllllllll}
\hline CV & 15.46 & 17.08 & 10.24 & 14.72 & 20.07 & 21.21 & 14.56 & 13.99 & 13.87 & 15.87 \\
\hline SD & 0.55 & 0.60 & 0.33 & 0.51 & 0.72 & 0.75 & 0.52 & 0.52 & 0.48 & 0.56 \\
mean & 3.57 & 3.53 & 3.25 & 3.50 & 3.61 & 3.53 & 3.54 & 3.72 & 3.46 & 3.52 \\
Min & 2.61 & 2.68 & 2.56 & 2.63 & 2.40 & 2.46 & 2.73 & 2.87 & 2.64 & 2.52 \\
$\max$ & 4.59 & 4.76 & 3.74 & 4.46 & 4.59 & 4.62 & 4.15 & 4.55 & 4.20 & 4.43 \\
\hline $\mathrm{R}^{2}$ & 0.24 & 0.29 & 0.12 & 0.03 & 0.08 & 0.15 & 0.25 & 0.29 & 0.01 & 0.12 \\
\hline
\end{tabular}

$\mathrm{CV}=$ Coefficient of Variability, $\mathrm{SD}=$ Standard Deviation, Min= Minimum, Max= Maximum, $\mathrm{R} 2=$ Coefficient of Determination

\subsection{Crop water requirement}

As indicated in Table 3 , the $\mathrm{K}_{\mathrm{c}}$ values $(0.5,0.76,1.14$ and 0.81$)$ and the water requirement of potato is $63.2,84.1$, 145.8 and $77.2 \mathrm{~mm}$ during initial, development, mid and late growth stages, respectively can be beneficial to areas with similar agro climatic condition as that of Cheha district for irrigation planning and management of potato. Generally, a potato with a growing period of 145 days to maturity would require $403.6 \mathrm{~mm}$ depth of water to achieve expected yield of production throughout single production season. Study conducted in India by [5], showed that a potato variety with 135 days to maturity requires $318.7 \mathrm{~mm}$ of water throughout the growing period. A potato variety with LGP of 160 days to maturity requires 414, 441 and $501 \mathrm{~mm}$ of water in Lemu, Golja and Sheled areas over the production season, respectively [3].

Table 3. Crop water requirement of potato in the study area

\begin{tabular}{llllll}
\hline Month & Decade & Stage & Kc coeff & ETc mm/day & ETc mm/dec \\
\hline Mar & 3 & Init & 0.5 & 1.8 & 16.2 \\
Apr & 1 & Init & 0.5 & 2.31 & 23.1 \\
Apr & 2 & Init & 0.5 & 2.39 & 23.9 \\
Apr & 3 & Deve & 0.58 & 2.24 & 22.4 \\
May & 1 & Deve & 0.77 & 2.94 & 29.4 \\
May & 2 & Deve & 0.95 & 3.23 & 32.3 \\
May & 3 & Mid & 1.12 & 3.85 & 42.4 \\
Jun & 1 & Mid & 1.15 & 3.7 & 37 \\
Jun & 2 & Mid & 1.15 & 3.77 & 37.7 \\
Jun & 3 & Mid & 1.15 & 3.33 & 33.3 \\
Jul & 1 & Mid & 1.15 & 2.87 & 28.7 \\
Jul & 2 & Late & 1.12 & 2.82 & 28.2 \\
Jul & 3 & Late & 0.91 & 2.32 & 25.5 \\
Aug & 1 & Late & 0.68 & 1.75 & 17.5 \\
Aug & 2 & Late & 0.53 & 1.49 & 6 \\
\hline Total & & & & 403.6 \\
\hline
\end{tabular}

$\mathrm{Kc}=$ Crop Coefficient, ETc $=$ Crop Water Requirement, dec $=$ Decade

\subsection{Net irrigation requirement}

As indicated in Table 4, the $\mathrm{K}_{\mathrm{c}}$ values $(0.5,0.76,1.14$ and 0.81$)$ and the net irrigation requirement of potato throughout the dry spell period is $52.9,61.3,14.9$ and $0 \mathrm{~mm}$ in initial, development, mid and late growth stages, respectively. In the aggregate value of about $129.1 \mathrm{~mm}$ depth of water is required as supplementary irrigation for potato crop grown in the area during dry and drought season for an individual farmer to offset the effect of water stress on potato yield. Therefore, absence of supplementary irrigation during dry season would result in reduced potato yield. Provision of irrigation is likely to play a strategic role in either stabilizing the production of crops or in supporting a low risk, high value production system with a strong commercial focus during rainfall shortage and prolonged dry season. The maximum irrigation requirement was higher also during the developmental stage of crop this might be due to the active development of the crop. It was lowest during late stages and was highest during development and initial stage. 
Table 4. Net irrigation requirement of potato in the study area

\begin{tabular}{c|c}
\hline Month in decade & Decadal Net Irr.Req. in mm \\
\hline 03-Mar & 5.9 \\
01-Apr & 23.1 \\
02-Apr & 23.9 \\
03-Apr & 0 \\
01-May & 29 \\
02-May & 32.3 \\
03-May & 0 \\
01-Jun & 1.4 \\
02-Jun & 0 \\
03-Jun & 3.1 \\
01-Jul & 10.4 \\
02-Jul & 0 \\
03-Jul & 0 \\
01-Aug & 0 \\
02-Aug & 0 \\
\hline Total & 129.1 \\
\hline
\end{tabular}

Net Irr.Req= Net Irrigation Requirement

\subsection{Effective rainfall contribution for CWR in the study area}

As shown in the Table 5, the effective rainfall contribution throughout the growing stage of potato in the area is $8.5,23,187.2$, and $158.1 \mathrm{~mm}$ all through initial, development, mid and late growth stages, respectively. Out of $403.6 \mathrm{~mm}$ depth of water about $377.5 \mathrm{~mm}$ is covered by effective rainfall of the locality, which is the only water available for root zone of potato after loss. Study conducted in by [5], showed the effective rainfall contribution for CWR is $176.5 \mathrm{~mm}$.

Table 5. Effective rainfall contribution for CWR in the study area

\begin{tabular}{c|c}
\hline Month in decade & ER in mm \\
\hline 03-Mar & 8.5 \\
01-Apr & 0 \\
02-Apr & 0 \\
03-Apr & 22.6 \\
01-May & 0.4 \\
02-May & 0 \\
03-May & 46.2 \\
01-Jun & 35.7 \\
02-Jun & 57.6 \\
03-Jun & 30.2 \\
01-Jul & 18.2 \\
02-Jul & 39.3 \\
03-Jul & 53.5 \\
01-Aug & 50 \\
02-Aug & 15.3 \\
\hline Total & 377.5 \\
\hline
\end{tabular}

$\mathrm{ER}=$ Effective Rainfall

\subsection{Crop coefficient $(\mathrm{Kc})$ in the function of growth stages}

Figure 2 below depict, crop stage of potato and summaries the main crop coefficient used for water management. There is crop coefficient variability trend with initial stage up to harvesting period, showed an increasing pattern from end of initial stage to end of development stage, almost constant values in the midseason stage and decreasing in the late stage. The chronology of Kc values proved that the value of Kc can varies with crop development/stages and can affect the level of water requirement of the crop due to physiological difference in the crop developmental stage. 


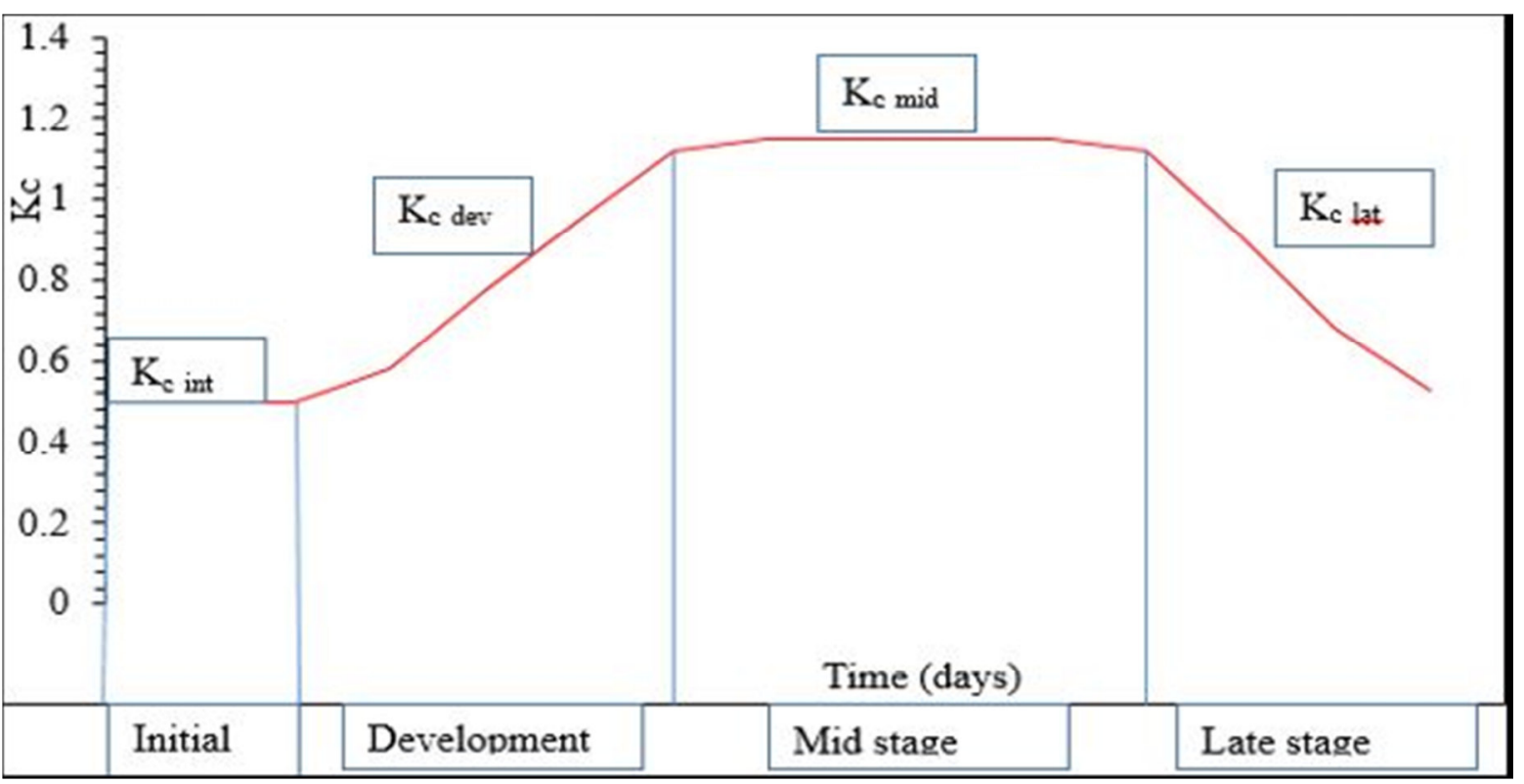

Kc int=crop coefficient at initial stage, $\mathrm{Kc} \mathrm{dev}=$ crop coefficient at development stage, Kc mid= crop coefficient at mid stage, $\mathrm{Kc}$ lat $=$ crop coefficient at late stage

Figure 2: Crop stage of potato and summaries the main crop coefficient used for water management

\subsection{Water requirement satisfaction index}

The WRSI for a 145 day to maturity potato variety planted between March-3 and Agust-1 period shows that an initial and development stage has 13.5 and $27.4 \%$ indices respectively, indicating a great coincidental of total failure for a 145 day to maturity potato grown under rain-fed condition in the area (Table 6). Thus, application of irrigation is very important in these two stage to reduce the impact of water shortage on potato yield. The WRSI indices for the mid and late stage is satisfactory in the area which is 104.9 and $204.8 \%$, respectively.

Table 6. Water requirement satisfaction index of the potato individual growth stage

\begin{tabular}{lccc}
\hline & ETc & ER & WRSI (\%) \\
\hline Initial stage & 63.2 & 8.5 & 13.5 \\
Development stage & 84.1 & 23 & 27.4 \\
Mid stage & 179.1 & 187.9 & 104.9 \\
\hline Late stage & 77.2 & 158.1 & 204.8 \\
\hline ETc= Crop Water Requirement, ER= Effective Rainfall, WRSI= Water Requirement Satisfaction index
\end{tabular}

\section{Conclusions}

The analyzed data indicated that reference crop evapotranspiration ranged from 2.40 to $4.73 \mathrm{~mm}$ with a mean of $3.56 \mathrm{~mm}$. The assessment has showed that the water requirement of potato is $63.2,84.1,145.8$ and $77.2 \mathrm{~mm}$ during initial, development, mid and late growth stages, respectively. The effective rainfall contribution throughout the growing stage of potato in the area is $8.5,23,187.2$ and $158.1 \mathrm{~mm}$ all through initial, development, mid and late growth stages, whereas the net irrigation requirement of potato during the dry spell period is 52.9, 61.3, 14.9 and $0 \mathrm{~mm}$ in initial, development, mid and late growth stages, respectively. The WRSI for a 145 day to maturity potato variety planted between March-3 and Agust-1 period shows that an initial and development stage has 13.5 and $27.4 \%$ indices, respectively.

\section{Recommendations}

On the basis of this study, the individual farmers of the study area should make available about $129.1 \mathrm{~mm}$ of water in the farm land to get high potato yield in the production season. To achieve this requirement, farmers of the area should apply the following list of recommendations.

Irrigation activities should be implemented and irrigation projects should be launched in the basic areas where Gogeb and Gotam rivers source can be used, as this can supports the farmers to overcome the stress created even on general agricultural sector not only potato production during the periods of rain shortage or recurrent drought and prolong dry spell.

If the water source is scarce (farmers who has not irrigation access) soil and water conservation management, water harvesting technology and agronomic practices should be applied, principally mulching is very important to save soil moisture during dry period. 


\section{Author contributions}

Solomon Abirdew Yirga wrote the first draft of the manuscript (proposal writing up to the final draft of the manuscript). I have read and approved the final manuscript

\section{Author details}

Solomon Abirdew Yirga, Lecturer and researcher at Wolkite University Department of Natural Resource Management, Wolkite Ethiopia

\section{Acknowledgements}

The author is highly thankful to the Wolkite University (WKU) for moral support through wrote a letter to take data from NMA. I also express my sincere thanks to the Ethiopian National Meteorological Agency for readily providing the daily temperatures, sun hours, wind speed and humidity data.

\section{Competing interests}

The author declare that has no competing interests

\section{Availability of data and materials}

The data will provide as per request of the journal

\section{Consent for publication}

Not applicable.

\section{Ethics approval and consent to participate}

Not applicable.

\section{Funding}

Not applicable

\section{References}

[1] Allen, R. G., Pereira, L. S., Raes, D. and Smith, M (1998) Crop Evapotranspiration; Guidelines for Computing Crop Water Requirements; FAO Irrigation and Drainage Paper No. 56. FAO, Rome, Italy.

[2] CDAO (Cheh District Agricultural Office) (2018) Cheha Woreda agricultural office, Imdibit, Ethiopia.

[3] Kassu Tadesse, Duga Debele, Amare Tadesse, Yared Derebe and Hirozumi Watanabe (2017) Effect of irrigation scheduling on productivity and water use efficiency of potato in south-eastern Ethiopia, International Journal of Plant Production 11 (3).

[4] Monteith (1965) "Evaporation and environment". Symposia of the Society for Experimental Biology 19:205224 PMID 5321565, Hydrology and watershed management.

[5] Nithya K.,B and Shivpur A.,V (2016) Study on the water requirement of selected crop under Tarike commar area using CROPWAT, Irrigation and drainage system engineering.

[6] Senay G.B. and J. Verdin, 2003. Characterization of Yield Reduction in Ethiopia Using a GIS-Based Crop Water Balance Model. Canadian Journal of Remote Sensing, 29(6):687- 69

[7] Solomon Abirdew, Girma Mamo and Mengistu Mengesha (2018) Determination of Crop Water Requirements for Maize in Abshege Woreda, Gurage Zone, Ethiopia. J Earth Sci Clim Change 9: 439. doi: $10.4172 / 2157-7617.1000439$

[8] Yenesew Mengiste (2015) Agricultural water productivity optimization for irrigated Teff (Eragrostic Tef) in water scarce semi-arid region of Ethiopia Agricultural water productivity optimization for irrigated Teff (Eragrostic Tef) in water scarce semi-arid region of Ethiopia. CRC Press/Balkema 